\title{
Lateral Spread of Three Warm-season Turfgrass Species as Affected by Prior Summer Water Stress at Two Root Zone Depths
}

\author{
Kurt Steinke \\ Department of Crop and Soil Sciences, Michigan State University, 1066 \\ Bogue Street, Plant and Soil Science Building, East Lansing, MI 48824
}

David R. Chalmers

Plant Sciences Department, South Dakota State University, Brookings, SD 57007

\author{
Richard H. White, Charles H. Fontanier, James C. Thomas, \\ and Benjamin G. Wherley \\ Soil and Crop Sciences Department, Texas A\&M University, College Station, \\ TX 77843-2474
}

Additional index words. bermudagrass, st. augustinegrass, zoysiagrass, drought recovery, regrowth

\begin{abstract}
As a result of increasing demand for potable water, local and national initiatives to conserve municipal water supplies have been implemented. Many of these initiatives focus on reducing irrigation of turfgrass in urban landscapes and may totally ban irrigation during periods of severe water shortage. Proper selection of adapted turfgrass species and cultivars is vital to long-term water conservation initiatives. Turfgrasses that can survive and recover from extended hot and dry periods under limited to no irrigation would best meet water conservation objectives. The present study was conducted to evaluate the recuperative potential of transplanted plugs of 24 commonly grown cultivars of three warm-season turfgrass species after incremental increases in water stress imposed by withholding all water for up to 60 days. A 2 -year field study was conducted consisting of eight blocks containing 25 plots each. Each block was planted with one plot each of eight cultivars of bermudagrass (Cynodon dactylon sp.), seven cultivars of st. augustinegrass (Stenotaphrum secundatum sp.), and nine cultivars of zoysiagrass (five of Zoysia japonica sp. and four of Zoysia matrella sp.). Four blocks were planted on native soil with no restriction to rooting, whereas the other four had an effective root zone of only $10 \mathrm{~cm}$ of soil. Cup cutter plugs were collected at predetermined intervals, transported to College Station, TX, replanted, and grown under well-watered conditions. Measurements of the lateral spread of the plugs were taken every 10 to 14 days for the first 60 to 70 days after planting (DAP). The lateral spread of plugs collected after 0 days of summer dry-down (DSD) was greatest for bermudagrass, intermediate for st. augustinegrass, and lowest for zoysiagrass. In most cases there were no consistent differences between cultivars within a species. All species grown on the $10-\mathrm{cm}$ deep root zone were unable to survive the 60-day period without water and died within the first 40 days. For each species, lateral spread was increasingly delayed or reduced with increasing DSD. Although all three species grown on native soil were able to survive and recover from a 60-day period without water, the bermudagrass cultivars had the most rapid recovery rates measured as lateral spread of transplanted plugs.
\end{abstract}

Municipal water supply systems are increasingly burdened by population growth, and public utilities often implement water use restrictions during periods of severe drought to ensure an adequate supply of potable water

Received for publication 24 Jan. 2013. Accepted for publication 1 May 2013.

This work was supported in part by grants from the San Antonio Water System and the Turfgrass Producers of Texas.

${ }^{1}$ To whom reprint requests should be addressed; e-mail jc-thomas@tamu.edu. characteristics as affected by water stress duration and genotype.

Although a group of different turfgrasses may experience the same climatic conditions, they may not all experience exactly the same degree of water stress as a result of various modes of drought avoidance. Such mechanisms include deep rooting (Huang et al., 1997a, 1997b; Marcum et al., 1995; Sheffer et al., 1987), rapid water uptake from deeper soil layers (Huang et al., 1997b), root branching at lower depths (Marcum et al., 1995), and preconditioning to water stress (Qian and Fry, 1996, 1997). More recent breeding efforts to develop dwarf-type grasses with lower mowing heights and greater plant densities have tended to result in shorter root systems and increased susceptibility to water stress (Qian et al., 1997; White et al., 1993).

The onset of limited soil moisture triggers a host of physiological actions within turfgrass plants. Increased levels of abscisic acid and reduced levels of cytokinin have been correlated with drought conditions and reduced levels of growth and transpiration (Assmann and Shimazaki, 1999; DaCosta and Huang, 2007). During the initial stages of drought, an increased amount of carbon is partitioned to the root system to increase root growth and exploration of the soil for water followed by increased carbon storage as carbohydrates in the leaves and stems for future use during drought recovery (DaCosta and Huang, 2006). Under severe drought conditions, many root and stem cells suffer damage to cell membranes causing leakage of solutes and electrolytes, which result in increased resistance to water transport and ultimately leads to plant death (Boyer, 1971; Huang et al., 1997b). Field evidence collected by Griffin and Hoffmann (2012) showed that mortality of two alpine grass species $(P$. hothamensis and $P$. hiemata) in Australia was directly related to the amount of plant-available water in the upper $6 \mathrm{~cm}$ of soil. Thus, drought of sufficient magnitude and duration may result in the death of the entire plant.

Recovery of turf from drought stress has only been studied to a limited extent and largely with cool-season grasses such as tall fescue (Huang et al., 1998), kentucky bluegrass (Wang and Huang, 2004), and bentgrass (DaCosta and Huang, 2007). Heckathorn et al. (1997) found that nitrogen levels in $\mathrm{C}_{4}$ prairie grasses were reduced during drought periods resulting in lower enzyme levels, which lowered photosynthetic activity for at least $14 \mathrm{~d}$ after the end of the drought period. Cathey et al. (2011) studied turf response to increasing water stress as measured by reduced transpiration rates in a greenhouse experiment and found that zoysiagrass reflected less stress in the plants as compared with bahiagrass and st. augustinegrass. The lower stress in zoysiagrass was attributed to a combination of this grass having a longer time of acclimation as a result of lower transpiration rates and greater osmotic regulation resulting in higher turgor pressures. 
The present study was conducted to evaluate the recuperative potential of transplanted plugs of 24 commonly grown cultivars of three species of warm-season turfgrasses subjected to varying amounts of water stress caused by prolonged withholding of water to plants grown in restricted $(10 \mathrm{~cm})$ and unrestricted root zones.

\section{Materials and Methods}

Plant materials used in this study originated from a parent experimental site located $\approx 4.8 \mathrm{~km}$ south of San Antonio, TX, on an area of Lewisville silty clay (fine-silty, mixed, thermic Udic Calciustoll) used for production of zoysiagrass sod. A rectangular area $\approx 30.5 \mathrm{~m}$ wide $\times 152 \mathrm{~m}$ long was cleared of sod and irrigation equipment. A $15.2 \mathrm{~m} \times 107-\mathrm{m}$ rectangular area within the cleared area was laser graded to provide level $15.2 \mathrm{~m} \times 30.5-\mathrm{m}$ experimental areas at each end. The area between the two experimental areas was given a $1 \%$ slope toward the center. A trench $60 \mathrm{~cm}$ wide, $107 \mathrm{~m}$ long, and $45 \mathrm{~cm}$ deep was cut along each side of the area to accommodate construction of a concrete footer and wall on which the tracks for a rain shelter could be mounted.

The parent experimental design was a randomized complete block consisting of eight blocks each, which were $6.1 \mathrm{~m} \times 6.1 \mathrm{~m}$. Each block was subdivided into 25 individual plots each, which were $1.2 \mathrm{~m} \times 1.2 \mathrm{~m}$. All 24 cultivars were planted in randomly selected plots within each block and block placement within the experimental area was randomized as well. Blocks were separated by a $60-\mathrm{cm}$ aisle on all sides. The soil on four blocks was undisturbed other than some light tillage and hand raking, representing native soil with unrestricted rooting potential. The remaining four blocks had an artificial barrier to root growth consisting of a $0.8-\mathrm{mm}$ thick sheet of high-density polyethylene (GSE Lining Technology, Inc., Houston, TX) installed at a depth of $10 \mathrm{~cm}$ to simulate locations having shallow soils over bedrock. To establish sustainable home landscapes, some municipalities are requiring home builders to ensure a minimum $10-\mathrm{cm}$ depth of topsoil on all landscaped areas. However, there are no data available to confirm the adequacy of this depth and whether special irrigation requirements are needed for landscapes planted on shallow soils of this nature. The plastic barrier simulated bedrock, which will largely block vertical growth of roots, restrict the downward movement of water, and alter soil moisture storage in the topsoil.

Irrigation was accomplished using a twozone automatic irrigation system controlled by an Irritrol Systems, KwikDial automatic sprinkler system (Irritrol, Riverside, CA). One zone controlled irrigation to the four blocks having the $10-\mathrm{cm}$ soil depth, whereas the second zone controlled irrigation to the four blocks with unrestricted soil depth. Each block was equipped with a pop-up rotor spray head (Model PGJ-06; Hunter Industries, San Marcos, CA) with a $7.6-\mathrm{L} \cdot \mathrm{min}^{-1}$ nozzle at each corner, providing head-tohead coverage.

To control weeds in the plot areas, all blocks were treated with granular Basamid G (dazomet; Certis USA, Columbia, MD) following label directions at the rate of 392 $\mathrm{kg} \cdot \mathrm{ha}^{-1}$.

A $464.5-\mathrm{m}^{2}$ movable rain shelter was constructed to protect the plots from undesired rainfall during the drought period. The rain shelter had a steel frame and a galvanized, corrugated metal roof. The sides were wrapped with plastic tarps to prevent entrance of blowing water. The rain shelter was programmed to automatically deploy and cover the research plots when a tipping bucket rain gauge detected $0.5 \mathrm{~mm}$ of precipitation. Ninety seconds were required for the rain shelter to fully cover the plots and protect them from unwanted rainfall. After 30 min of not recording any rainfall during a rain event, the rain shelter returned to its center position.

Grasses evaluated in this parent study included eight cultivars of bermudagrass (Cynodon dactylon sp.) ('Celebration', 'Common', 'GN-1', 'Grimes EXP', 'Premier', 'TexTurf', 'TifSport', and 'Tifway'); seven cultivars of st. augustinegrass (Stenotaphrum secundatum sp.) ('Amerishade', 'Common', 'Delmar', 'Floratam', 'Palmetto', 'Raleigh', and 'Sapphire'); and nine cultivars of zoysiagrass (Zoysia japonica Steud.) ('El Toro', 'Emerald', 'Empire', 'Jamur', and 'Palisades') and [Zoysia matrella (L.) Merr.] ('Cavalier', 'Y2', 'Zeon', and 'Zorro'). These grasses were selected to be representative of either the most commonly grown warm-season grasses for home lawns in central Texas or the most promising cultivars being developed for marketing to homeowners by central Texas sod producers.

Sod was sourced from the same growers in each study year. All sod was well established and suitable for harvest and commercial sale. Sod was cut by producers, washed to remove the majority of soil, labeled, placed on pallets, and stored overnight in a refrigerated truck trailer. The washed sod was brought to the experimental site the next morning for planting. Planting dates were 20 Sept. 2005 and 22 Sept. 2006. Sod was grown and allowed to establish 9 months before withholding all water for a 60 -d period. The starting and ending dates for the $60-\mathrm{d}$ periods without water were 23 July 2006 to 21 Sept. 2006 and 5 July 2007 to 3 Sept. 2007 . The study was initially done on the east end of the site in 2005 to 2006 and repeated on the west end of the site in 2006 to 2007 . Additional details on site preparation and planting can be found in Chalmers et al. (2008).

Environmental conditions were more stressful in 2006 as compared with 2007. Average high temperatures during the first $40 \mathrm{~d}$ of the experiment were 35.9 and $31.3^{\circ} \mathrm{C}$ for 2006 and 2007, respectively. In addition, the total potential evapotranspiration (PET) for the first $40 \mathrm{~d}$ of the experiment were 6.46 and $4.27 \mathrm{~mm} \cdot \mathrm{d}^{-1}$ for 2006 and 2007 , respectively (Steinke et al., 2010). Thus, plants in the first year experienced a higher degree of both evaporative demand and temperature stress.

A standard cup cutter was used to remove a $10-\mathrm{cm}$ diameter, $7-\mathrm{cm}$ deep plug of grass from each parent plot at the start of the summer dry-down treatment (Day 0) and at 20,40 , and 60 DSD. To minimize the potential for sampling bias, plugs were removed from near the center of the same quadrant of all parent plots at a given sampling date. Plugs collected at the start of the experiment (0 DSD) served as the controls. Holes from sampling were filled with topsoil from the adjacent field. Each plug was placed in a labeled plastic 4-L zip-lock bag. Bags were left open to the air and immediately transported in an air-conditioned vehicle to College Station, where they were planted at $60-\mathrm{cm}$ centers in an irrigated section of Booneville fine sandy loam (Fine, smectitic, thermic Chromic Vertic Albaqualf). Planting in a different soil and location was necessary to be able to carefully monitor irrigation and to be able to make relatively frequent measurements of lateral spread. Because all species and cultivars were moved between the same two locations, it was assumed that the effects would be similar across all grasses.

The planting areas were irrigated daily as needed to prevent stress. No pre-plant or supplemental fertilizer was added. A $10 \times$ 10 quadrat $(6 \mathrm{~cm} \times 6-\mathrm{cm}$ cells $)$ was laid over each plug on the day of planting and each 10to 14-d interval thereafter. The number of squares containing live plant material originating from the original plug were counted, recorded, and converted to $\mathrm{cm}^{2}$. The original plug at planting had live plant material in four squares of the quadrat corresponding to a beginning area of $144 \mathrm{~cm}^{2}$.

All data were subjected to analysis of variance using the general linear model, multivariate test procedure in SPSS Version 15.0 (IBM Corp., Armonk, NY) to determine statistical significance of the results. Mean differences were separated using Tukey's honestly significant difference procedure at a significance level of $P \leq 0.05$.

\section{Results and Discussion}

Lateral spread. The lateral spread of cup cutter plugs collected after 0 DSD (i.e., immediately before water was withheld) served as a measure of the potential growth rate for each species. The data were pooled by species within each year, and the mean spread for cup cutter plugs of each species is shown in Figures 1 and 2 for years 2006 and 2007, respectively.

In 2006, plugs collected after 0 DSD initiated lateral spread quickly. By 26 and 56 DAP, bermudagrass spread had increased to 1070 and $3255 \mathrm{~cm}^{2}$, which was $\approx 7.4$ and 22.6 times their initial areas, respectively. The rate of lateral spread of bermudagrass was best described by a second order polynomial equation. After 26 DAP and at all dates thereafter, st. augustinegrass spread was significantly less than bermudagrass. Although slower, the rate of spread of st. augustinegrass 
2006

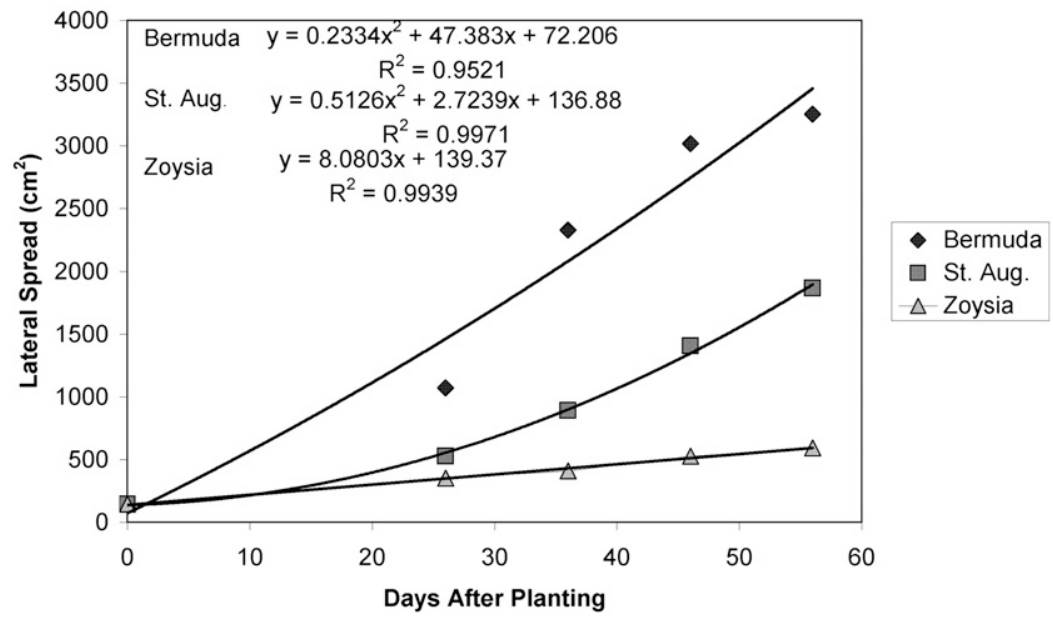

Fig. 1. Mean spread $\left(\mathrm{cm}^{2}\right)$ with time of transplanted plugs of bermudagrass (Bermuda), st. augustinegrass (St. Aug.), and zoysiagrass (Zoysia) collected immediately before the summer dry-down in 2006.

\section{7}

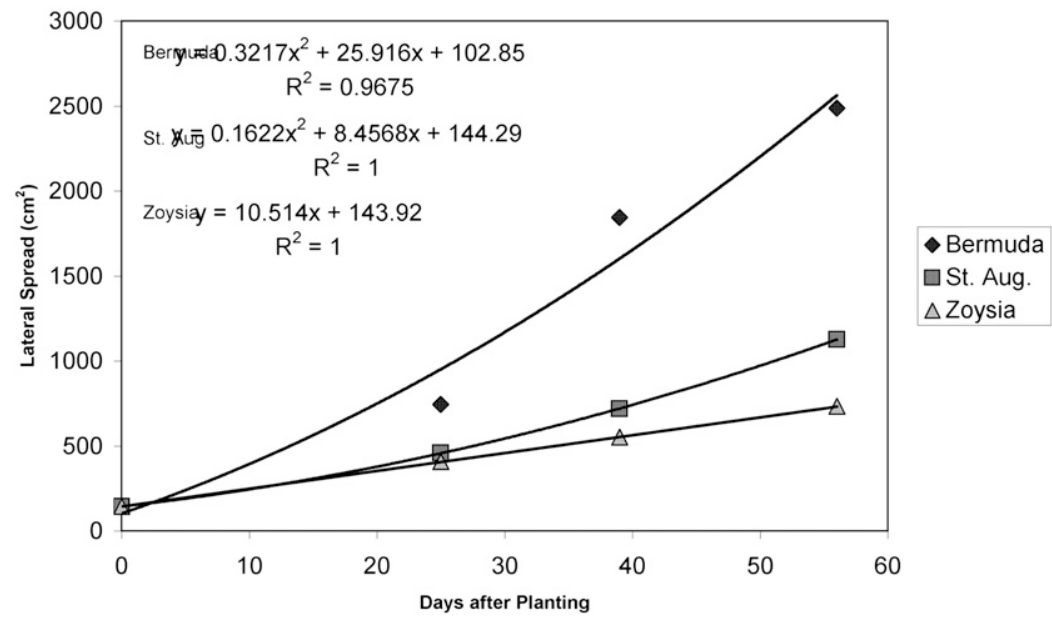

Fig. 2. Mean spread $\left(\mathrm{cm}^{2}\right)$ with time of transplanted plugs of bermudagrass (Bermuda), st. augustinegrass (St. Aug.), and zoysiagrass (Zoysia) collected immediately before the summer dry-down in 2007.

\section{6}

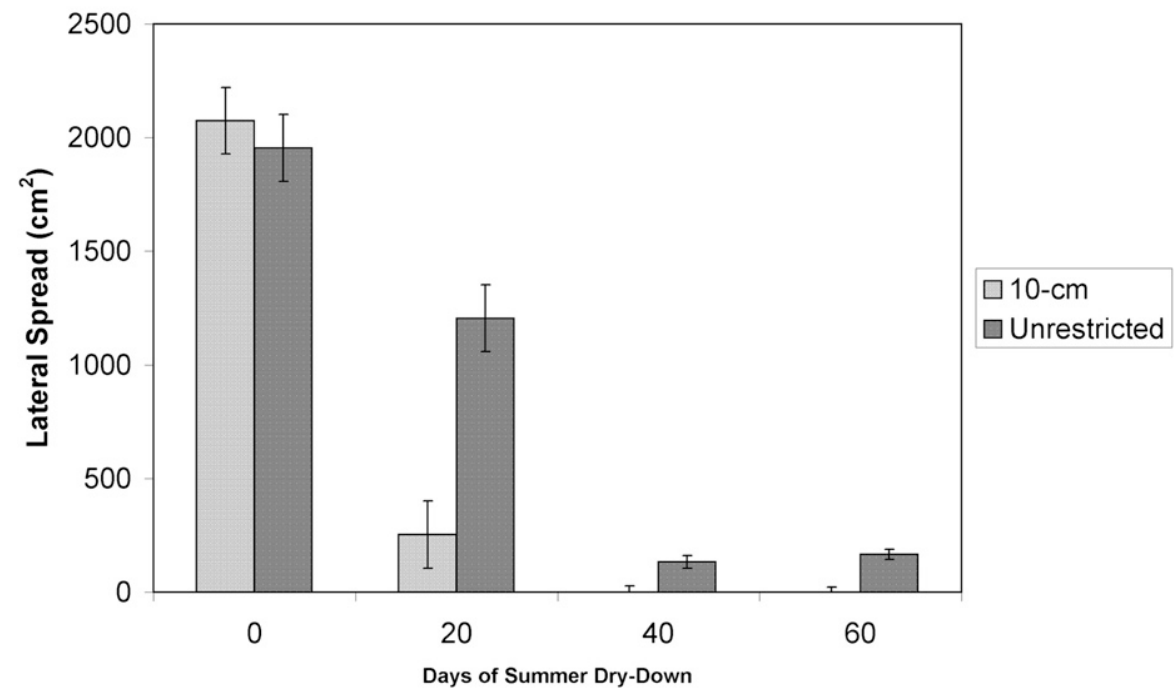

Fig. 3. Mean spread of plugs of bermudagrass, st. augustinegrass, and zoysiagrass collected after $0,20,40$, and $60 \mathrm{~d}$ of summer dry-down as affected by root zone depth (unrestricted and $10 \mathrm{~cm}$ ) during 2006. Error bars represent the $95 \%$ confidence interval. plugs followed a similar trend as bermudagrass and was also best described by a second-order polynomial equation. At 26 and 56 DAP, st. augustinegrass spread increased to 526 and $1866 \mathrm{~cm}^{2}$, which was $\approx 3.6$ and 13 times their initial areas, respectively. Of the three species in this study, zoysiagrass plugs exhibited the slowest rate of spread. The zoysiagrass plugs exhibited a linear increase in area from 351 $\mathrm{cm}^{2}$ at 26 DAP to $593 \mathrm{~cm}^{2}$ at 56 DAP, which was $\approx 2.4$ and 4.1 times their initial areas, respectively.

Rates of spread for the plugs collected after 0 DSD in the 2007 growing season were similar to 2006 with bermudagrass having the most rapid spread, followed by st. augustinegrass, and finally zoysiagrass. Mean spread areas at 56 DAP were 2487, 1127, and $733 \mathrm{~cm}^{2}$ for bermudagrass, st. augustinegrass, and zoysiagrass, respectively. These values represented an increase of $\approx 17.3,7.8$, and 5.1 times their initial areas. In comparison with 2006, rates of spread for bermudagrass and st. augustinegrass were slightly lower in 2007, whereas that for zoysiagrass was slightly greater.

Of the three species tested over both years, they ranked as bermudagrass $>$ st. augustinegrass $>$ zoysiagrass from greatest to lowest rate of spread. These results are in general agreement with previous understanding of recuperative potential from general cover loss among turfgrass species (Beard, 1973; Cathey et al., 2011). The trends in recovery rates from this study are also consistent with measured differences in divot recovery rates between species (Trappe et al., 2010).

These data point to the need for caution when evaluating the recovery of grasses from stresses. As a result of the inherently slower lateral growth rates of st. augustinegrass and particularly zoysiagrass, these grasses will require more time to resume lateral spread after sustaining damage or injury. However, this should not be misinterpreted to mean that they are less able to recover from damage or injury.

Restricted root zone. In 2006, plugs collected after 0 DSD from both root zone depths demonstrated good survivability and achieved lateral spread ranging from 1955 to $2074 \mathrm{~cm}^{2}$ (Fig. 3). Plugs collected after 0 DSD from both root zone depths had similar amounts of spread. However, root zone depth had a strong effect on plug survival and recovery of drought-stressed turfs. Plugs from both root zone depths collected after experiencing 20 DSD exhibited much lower amounts of spread than those collected after 0 DSD (Fig. 3). Plugs from the $10-\mathrm{cm}$ root zone exhibited significantly less spread than those from the unrestricted root zone. Plugs from the unrestricted root zone treatment after 40 and 60 DSD performed poorly and exhibited very little spread. In comparison, the majority of plugs from the $10-\mathrm{cm}$ root zone treatment collected after 40 and 60 DSD died.

Weather conditions in the 2007 growing season were less severe with lower daily 
maximum temperatures (Steinke et al., 2010) and lower daily PET amounts (Steinke et al., 2011) and resulted in improved growth and spread of plugs collected from the unrestricted root zone treatment (Fig. 4) after 20, 40, and 60 DSD. However, even with the milder conditions in 2007 , the majority of plugs from the $10-\mathrm{cm}$ root zone treatment collected after 40 and 60 DSD died.

The Lewisville soil series is estimated to contain $0.15 \mathrm{~cm} \cdot \mathrm{cm}^{-1}$ available water $(0.33$ to 15.0 bar water retention) in the upper $12.7 \mathrm{~cm}$ of the soil profile (Soil Conservation Service, U.S. Department of Agriculture, 1976). The 10-cm root zone depth used in this study would have held $\approx 1.5 \mathrm{~cm}$ of plant-available water. Because the profile was truncated at 10 $\mathrm{cm}$, one may argue that the profile may have been nearly saturated at the start of the experiment. In this case, the profile would have contained a maximum of $3.6 \mathrm{~cm}$ plantavailable water. At a modest use of only 3 $\mathrm{mm} \cdot \mathrm{d}^{-1}$, this water would have been exhausted in $12 \mathrm{~d}$ after which the plant tissues would have begun to desiccate and suffer permanent damage.

The high mortality of plugs coming from the $10-\mathrm{cm}$ root zone after 40 and 60 DSD is

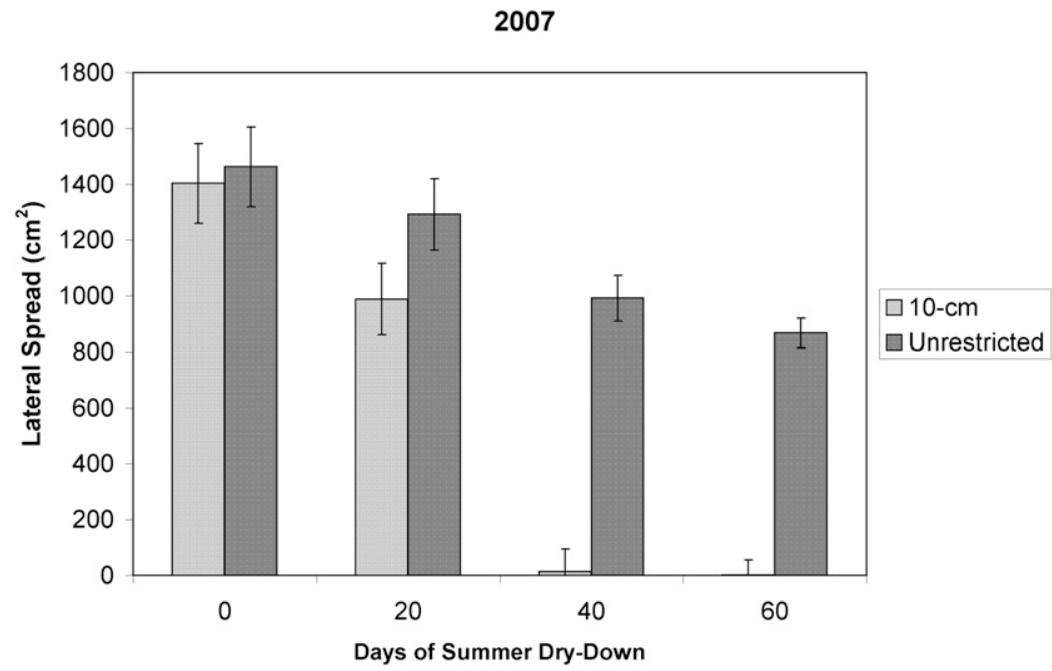

Fig. 4. Mean spread of plugs of bermudagrass, st. augustinegrass, and zoysiagrass collected after 0, 20, 40, and $60 \mathrm{~d}$ of summer dry-down as affected by root zone depth (unrestricted and $10 \mathrm{~cm}$ ) during 2007. Error bars represent the $95 \%$ confidence interval.

Table 1. Mean turf-covered area $\left(\mathrm{cm}^{2}\right)$ of bermudagrass plugs from the unrestricted root zone plots $\approx 25$ and $56 \mathrm{~d}$ after planting (DAP) and subject to 0, 20, 40, and $60 \mathrm{~d}$ of summer dry-down (DSD) in 2006 and 2007.

\begin{tabular}{|c|c|c|c|c|c|c|c|c|}
\hline \multirow[b]{4}{*}{ Cultivar } & \multicolumn{8}{|c|}{ 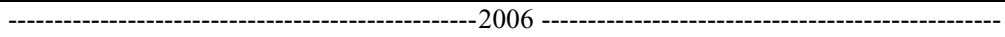 } \\
\hline & \multicolumn{2}{|c|}{0 DSD plugs } & \multicolumn{2}{|c|}{20 DSD plugs } & \multicolumn{2}{|c|}{40 DSD plugs } & \multicolumn{2}{|c|}{60 DSD plugs } \\
\hline & \multicolumn{8}{|c|}{ - } \\
\hline & 26 DAP & 56 DAP & 30 DAP & 60 DAP & 30 DAP & 60 DAP & 25 DAP & 55 DAP \\
\hline GN1 & $1213 \mathrm{abc}^{\mathrm{y}}$ & $3600 \mathrm{a}$ & $385 \mathrm{a}$ & $2329 \mathrm{a}$ & $156 \mathrm{a}$ & $205 \mathrm{a}$ & $169 \mathrm{ab}$ & $313 \mathrm{bc}$ \\
\hline TexTurf & $660 \mathrm{bcd}$ & $3600 \mathrm{a}$ & $324 \mathrm{a}$ & $1393 \mathrm{a}$ & $180 \mathrm{a}$ & $277 \mathrm{a}$ & $156 \mathrm{ab}$ & $324 \mathrm{~b}$ \\
\hline Premier & $840 \mathrm{bcd}$ & $3600 \mathrm{a}$ & $288 \mathrm{a}$ & $1656 \mathrm{a}$ & $144 \mathrm{a}$ & $144 \mathrm{a}$ & $144 \mathrm{~b}$ & $144 \mathrm{c}$ \\
\hline Grimes Exp & $1308 \mathrm{ab}$ & $3600 \mathrm{a}$ & $385 \mathrm{a}$ & $2244 \mathrm{a}$ & $169 \mathrm{a}$ & $228 \mathrm{a}$ & $192 \mathrm{a}$ & $457 \mathrm{ab}$ \\
\hline TifSport & $565 \mathrm{~cd}$ & $2149 \mathrm{~b}$ & $277 \mathrm{a}$ & $997 \mathrm{a}$ & $156 \mathrm{a}$ & $169 \mathrm{a}$ & $144 \mathrm{~b}$ & $324 \mathrm{~b}$ \\
\hline TifWay & $504 \mathrm{~d}$ & $2352 b$ & $349 \mathrm{a}$ & $1512 \mathrm{a}$ & $192 \mathrm{a}$ & $264 \mathrm{a}$ & $144 \mathrm{~b}$ & $349 \mathrm{~b}$ \\
\hline Celebration & $1152 \mathrm{abcd}$ & $3600 \mathrm{a}$ & $324 a$ & $2113 \mathrm{a}$ & $169 a$ & $205 \mathrm{a}$ & $156 \mathrm{ab}$ & $565 \mathrm{a}$ \\
\hline \multirow[t]{2}{*}{ Common } & $1632 \mathrm{a}$ & $3600 \mathrm{a}$ & $385 \mathrm{a}$ & $1825 \mathrm{a}$ & $144 \mathrm{a}$ & $144 \mathrm{a}$ & $156 \mathrm{ab}$ & $349 \mathrm{~b}$ \\
\hline & \multicolumn{2}{|c|}{0 DSD plugs } & \multicolumn{2}{|c|}{20 DSD plugs } & \multicolumn{2}{|c|}{40 DSD plugs } & \multicolumn{2}{|c|}{60 DSD plugs } \\
\hline Cultivar & 25 DAP & 56 DAP & 25 DAP & 53 DAP & 31 DAP & 61 DAP & 25 DAP & 57 DAP \\
\hline$\overline{\mathrm{GN} 1}$ & 804 abc & $3036 \mathrm{ab}$ & $612 \mathrm{~b}$ & $2844 \mathrm{a}$ & $673 \mathrm{a}$ & 1272 bc & $408 \mathrm{~b}$ & $1776 \mathrm{ab}$ \\
\hline TexTurf & $457 \mathrm{c}$ & $1897 \mathrm{~b}$ & $432 \mathrm{~b}$ & $1393 \mathrm{~b}$ & $576 \mathrm{a}$ & $1056 \mathrm{bc}$ & $408 \mathrm{~b}$ & $828 \mathrm{c}$ \\
\hline Premier & $480 \mathrm{c}$ & $1980 \mathrm{~b}$ & $516 \mathrm{~b}$ & $2340 \mathrm{ab}$ & $745 \mathrm{a}$ & $1260 \mathrm{bc}$ & $372 \mathrm{~b}$ & $1380 \mathrm{bc}$ \\
\hline Grimes Exp & $792 \mathrm{abc}$ & $3036 \mathrm{ab}$ & $1141 \mathrm{a}$ & $2952 \mathrm{a}$ & $1200 \mathrm{a}$ & $2460 \mathrm{a}$ & $576 \mathrm{ab}$ & $1429 \mathrm{abc}$ \\
\hline TifSport & $516 \mathrm{c}$ & $2509 \mathrm{ab}$ & $540 \mathrm{~b}$ & $2041 \mathrm{ab}$ & $588 \mathrm{a}$ & $1213 \mathrm{bc}$ & 396 b & $1008 \mathrm{bc}$ \\
\hline TifWay & $684 \mathrm{bc}$ & $2365 \mathrm{ab}$ & $504 \mathrm{~b}$ & $2016 \mathrm{ab}$ & $516 a$ & $732 \mathrm{c}$ & $432 \mathrm{ab}$ & 997 bc \\
\hline Celebration & $1308 \mathrm{a}$ & 3193 a & $709 \mathrm{~b}$ & $2496 \mathrm{ab}$ & $696 a$ & $1501 \mathrm{abc}$ & 709 a & $2556 \mathrm{a}$ \\
\hline Common & $1200 \mathrm{ab}$ & $2952 \mathrm{ab}$ & $804 \mathrm{ab}$ & $2748 \mathrm{a}$ & $853 \mathrm{a}$ & $2052 \mathrm{ab}$ & $480 \mathrm{ab}$ & $1717 \mathrm{ab}$ \\
\hline
\end{tabular}

${ }^{\mathrm{z}}$ Area was calculated as the total area of all quadrat cells containing live plant material originating from the original plug.

${ }^{\mathrm{y}}$ Values in a given column and year followed by the same letter do not differ at $P \leq 0.05$.

consistent with corresponding observations of the death of the entire plots in these treatments (Chalmers et al., 2008). It is believed that plants growing in native soil were able to extend their roots into lower layers of the soil profile and remove small amounts of water sufficient to keep the crowns of the plants hydrated through a process known as hydraulic redistribution (Neumann and Cardon, 2012). However, plants in the $10-\mathrm{cm}$ root zone could not access this water resulting in complete desiccation and death of the plant crown.

These data reinforce the need for more frequent irrigation of turf grown on shallow topsoil during periods of drought and associated water use restrictions. Thus, drought management irrigation restrictions should be site-specific and accommodate regional soil types and depths. If possible, increasing soil depths on new construction should be encouraged as a way of improving turfgrass survival. Otherwise, more frequent irrigation will need to be allowed to maintain living turfgrass and avoid the need for replanting.

Bermudagrass cultivars. Comparisons of lateral spread among bermudagrass cultivars at $\approx 25$ and 56 DAP for each collection date in both years are shown in Table 1. In 2006, plugs collected after 0 DSD re-established and spread slowly for the first $26 \mathrm{~d}$. Over the next $30 \mathrm{~d}$, six of the cultivars exhibited very rapid spread and by 56 DAP had achieved a spread of $3600 \mathrm{~cm}^{2}$. 'TifSport' and 'Tifway' were the slowest to spread and only reached a spread of 2149 and $2352 \mathrm{~cm}^{2}$, respectively. Plugs collected after 20 DSD had low rates of lateral spread ranging from 277 to $385 \mathrm{~cm}^{2}$ at 30 DAP. The total spread of 997 to $2329 \mathrm{~cm}^{2}$ measured at 60 DAP was much less than that of the 0 DSD plugs. Plugs harvested after 40 and 60 DSD displayed limited lateral spread not exceeding $565 \mathrm{~cm}^{2}$.

In 2007, plugs collected after 0 DSD performed similarly to the previous year with a low amount of lateral spread at 25 DAP but reaching as high as $3193 \mathrm{~cm}^{2}$ at 56 DAP. Maximum amounts of spread for plugs exposed to 20,40, and 60 DSD were higher than those measured in 2006 presumably as a result of the lower evapotranspiration (ET) rates and higher humidity levels during the 2007 season. Rankings between the bermudagrass cultivars on four measurement sets in 2006 and one in 2007 were nonsignificant at the $P \leq 0.05$ level. On the remaining dates, rankings among cultivars frequently changed indicating variability in performance as a result of site-specific conditions at the parent site.

St. augustinegrass cultivars. Comparisons of lateral spread among st. augustinegrass cultivars at $\approx 25$ and 56 DAP for each collection date in both years are shown in Table 2. In 2006, plugs collected after 0 DSD re-established and spread slowly for the entire $56 \mathrm{~d}$ and exhibited a total spread of 997 to $2304 \mathrm{~cm}^{2}$. 'Amerishade' appeared to be the slowest to spread and only reached $997 \mathrm{~cm}^{2}$. Plugs harvested after 20 DSD had minimal lateral spread ranging from 277 to 
$360 \mathrm{~cm}^{2}$ at 30 DAP. The total spread ranging from 408 to $1285 \mathrm{~cm}^{2}$ measured at 60 DAP was approximately half that of the 0 DSD plugs. Plugs harvested after 40 and 60 DSD displayed lateral spread not exceeding $288 \mathrm{~cm}^{2}$.

In 2007, st. augustinegrass plugs harvested at 0 DSD also had a low amount of lateral spread for the entire 56 DAP. The 0 DSD plugs exhibited a total spread of 745 to $1548 \mathrm{~cm}^{2}$ at 56 DAP. Maximum amounts of spread for the plugs harvested after 20 DSD were similar to those measured in 2006. Maximum amounts of spread for the 40 and 60 DSD plugs were slightly higher in 2007 as compared with 2006 , presumably as a result of the slightly milder growing conditions (lower daytime temperatures and higher relative humidity) during the 2007 season. Rankings among the st. augustinegrass cultivars on three measurement sets in 2006 and four sets in 2007 were nonsignificant at the $P \leq 0.05$ level. On the remaining dates, rankings among cultivars frequently changed indicating variability in performance as a result of site-specific conditions at the parent site.

In general, the st. augustinegrass cultivar data indicate that the grasses spread less aggressively than bermudagrass cultivars under similar stress levels. In addition, these data demonstrate that a 56-d recovery period may be required before rapid regrowth and lateral spreading occurs.

Zoysiagrass cultivars. In 2006, zoysiagrass plugs harvested at 0 DSD spread very slowly reaching only 349 to $889 \mathrm{~cm}^{2}$ at 56 DAP (Table 3). Like with other species, plugs harvested after 20 DSD were slower to spread than those collected at 0 DSD. The plugs collected after 40 and 60 DSD survived but spread very little over the 55- to 60-d measurement period. The data from the 0 DSD plugs in 2007 also demonstrated slow rates of spread. Data for the 20, 40, and 60 DSD plugs in 2007 showed little reduction in the final spread values as compared with those of the 0 DSD plugs. This improved growth rate may be the result of the lower ET rates and higher humidity levels during the 2007 season. Rankings among the zoysiagrass cultivars on four measurement sets in 2006 and one set in 2007 were nonsignificant at the $P \leq$ 0.05 level. On the remaining dates, rankings among cultivars frequently changed, indicating variability in performance as a result of site-specific conditions at the parent site.

The data presented in this study indicate that the longer the exposure to drought, the greater the time delay before resumption of growth, measured as lateral spread of transplanted plugs. Similar delays in regrowth or recovery of physiological functions after imposed water stress treatments have been reported by other researchers (DaCosta and Huang, 2007; Huang et al., 1997b, 1998). Thus, as the duration and severity of a drought increase, the more physiological damage is done to the plant and the longer the time period required before plant growth can be re-established. However, even under the very stressful climatic conditions of 2006, all of the tested grasses grown on native soil in the parent field experiment were able to survive the 60 DSD period during which all water was withheld (Chalmers et al., 2008).

\section{Conclusions}

The data from the current study indicate that growth rates measured as lateral spread are species-dependent. Among species used in this study, recuperative potential was ranked as follows: bermudagrass $>$ st. augustinegrass $>$ zoysiagrass. The data also demonstrate a strong influence of root zone depth on the ability of the tested grasses to withstand extended periods without water. Grasses grown in $10-\mathrm{cm}$ deep root zones were unable

Table 2. Mean turf-covered area $\left(\mathrm{cm}^{2}\right)$ of st. augustinegrass plugs from the unrestricted root zone plots $\approx 25$ and $56 \mathrm{~d}$ after planting (DAP) and subject to 0, 20, 40, and $60 \mathrm{~d}$ of summer dry-down (DSD) in 2006 and 2007 . $^{\mathrm{z}}$

\begin{tabular}{|c|c|c|c|c|c|c|c|c|}
\hline \multirow[b]{3}{*}{ Cultivar } & \multicolumn{2}{|c|}{0 DSD plugs } & \multicolumn{2}{|c|}{20 DSD plugs } & \multicolumn{2}{|c|}{40 DSD plugs } & \multicolumn{2}{|c|}{60 DSD plugs } \\
\hline & \multicolumn{8}{|c|}{ - } \\
\hline & $26 \mathrm{DAP}$ & 56 DAP & 30 DAP & 60 DAP & 30 DAP & 60 DAP & 25 DAP & $55 \mathrm{DAP}$ \\
\hline Amerishade & $396 b^{y}$ & $997 \mathrm{~b}$ & $300 \mathrm{ab}$ & $624 \mathrm{~b}$ & $144 \mathrm{~b}$ & $169 \mathrm{a}$ & $144 \mathrm{a}$ & $156 \mathrm{a}$ \\
\hline Common & $720 \mathrm{a}$ & $2304 \mathrm{a}$ & $288 \mathrm{ab}$ & $673 \mathrm{ab}$ & $144 \mathrm{~b}$ & $288 \mathrm{a}$ & $144 \mathrm{a}$ & $144 \mathrm{a}$ \\
\hline Delmar & $385 \mathrm{~b}$ & $1416 \mathrm{ab}$ & $360 \mathrm{a}$ & $984 \mathrm{ab}$ & $192 \mathrm{ab}$ & $277 \mathrm{a}$ & $144 \mathrm{a}$ & $144 \mathrm{a}$ \\
\hline Floratam & $540 \mathrm{ab}$ & $2028 \mathrm{ab}$ & $277 \mathrm{~b}$ & $408 \mathrm{~b}$ & $144 \mathrm{~b}$ & $144 \mathrm{a}$ & $156 \mathrm{a}$ & $228 \mathrm{a}$ \\
\hline Palmetto & $552 \mathrm{ab}$ & $1884 \mathrm{ab}$ & $288 \mathrm{ab}$ & $660 \mathrm{ab}$ & $205 \mathrm{ab}$ & $205 \mathrm{a}$ & $144 \mathrm{a}$ & $144 \mathrm{a}$ \\
\hline Raleigh & $576 \mathrm{ab}$ & $1609 \mathrm{ab}$ & $300 \mathrm{ab}$ & $709 \mathrm{ab}$ & $144 \mathrm{~b}$ & $216 \mathrm{a}$ & $144 \mathrm{a}$ & $216 \mathrm{a}$ \\
\hline Sapphire & $421 \mathrm{~b}$ & $1728 \mathrm{ab}$ & $324 \mathrm{ab}$ & $1285 \mathrm{a}$ & $277 \mathrm{a}$ & $288 \mathrm{a}$ & $144 \mathrm{a}$ & $144 \mathrm{a}$ \\
\hline
\end{tabular}

\begin{tabular}{|c|c|c|c|c|c|c|c|c|}
\hline \multirow[b]{2}{*}{ Cultivar } & \multicolumn{2}{|c|}{0 DSD plugs } & \multicolumn{2}{|c|}{20 DSD plugs } & \multicolumn{2}{|c|}{40 DSD plugs } & \multicolumn{2}{|c|}{60 DSD plugs } \\
\hline & 25 DAP & 56 DAP & 25 DAP & 53 DAP & 31 DAP & 61 DAP & $25 \mathrm{DAP}$ & 57 DAP \\
\hline Amerishade & $421 \mathrm{a}$ & $745 \mathrm{a}$ & $349 \mathrm{a}$ & $576 \mathrm{~b}$ & $421 \mathrm{a}$ & $817 \mathrm{a}$ & $313 \mathrm{a}$ & $385 \mathrm{~b}$ \\
\hline Common & $493 \mathrm{a}$ & $925 \mathrm{a}$ & $396 a$ & $961 \mathrm{ab}$ & $396 \mathrm{a}$ & $1465 \mathrm{a}$ & $372 \mathrm{a}$ & $804 \mathrm{ab}$ \\
\hline Delmar & $468 \mathrm{a}$ & $864 \mathrm{a}$ & $385 \mathrm{a}$ & $732 \mathrm{~b}$ & $421 \mathrm{a}$ & $925 \mathrm{a}$ & $372 \mathrm{a}$ & $648 \mathrm{ab}$ \\
\hline Floratam & $529 \mathrm{a}$ & $1548 \mathrm{a}$ & $408 \mathrm{a}$ & $984 \mathrm{ab}$ & $396 \mathrm{a}$ & $1020 \mathrm{a}$ & $324 \mathrm{a}$ & $696 \mathrm{ab}$ \\
\hline Palmetto & $468 \mathrm{a}$ & $936 \mathrm{a}$ & $432 \mathrm{a}$ & $948 \mathrm{ab}$ & $432 \mathrm{a}$ & $660 \mathrm{a}$ & $360 \mathrm{a}$ & $756 a b$ \\
\hline Raleigh & $432 \mathrm{a}$ & $1368 \mathrm{a}$ & $408 \mathrm{a}$ & $925 \mathrm{ab}$ & $421 \mathrm{a}$ & 864 a & $349 \mathrm{a}$ & 889 a \\
\hline Sapphire & $468 \mathrm{a}$ & $1308 \mathrm{a}$ & $396 \mathrm{a}$ & $1296 \mathrm{a}$ & $432 \mathrm{a}$ & $1152 \mathrm{a}$ & $360 \mathrm{a}$ & $817 \mathrm{ab}$ \\
\hline
\end{tabular}

${ }^{\mathrm{z}}$ Area was calculated as the total area of all quadrat cells containing live plant material originating from the original plug.

${ }^{y}$ Values in a given column and year followed by the same letter do not differ at $P \leq 0.05$.

Table 3. Mean turf-covered area $\left(\mathrm{cm}^{2}\right)$ of zoysiagrass plugs from the unrestricted root zone plots $\approx 25$ and $56 \mathrm{~d}$ after planting (DAP) and subject to $0,20,40$, and $60 \mathrm{~d}$ of summer dry-down (DSD) in 2006 and $2007 .^{\mathrm{z}}$

\begin{tabular}{|c|c|c|c|c|c|c|c|c|}
\hline \multirow[b]{4}{*}{ Cultivar } & \multicolumn{8}{|c|}{ 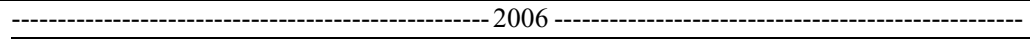 } \\
\hline & \multicolumn{2}{|c|}{0 DSD plugs } & \multicolumn{2}{|c|}{20 DSD plugs } & \multicolumn{2}{|c|}{40 DSD plugs } & \multicolumn{2}{|c|}{60 DSD plugs } \\
\hline & \multicolumn{8}{|c|}{ 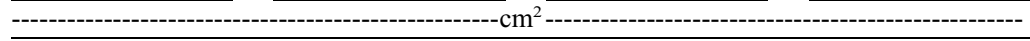 } \\
\hline & 26 DAP & 56 DAP & 30 DAP & 60 DAP & 30 DAP & 60 DAP & 25 DAP & 55 DAP \\
\hline Cavalier & $324 \mathrm{bc}^{\mathrm{y}}$ & $385 \mathrm{c}$ & $288 \mathrm{a}$ & $372 \mathrm{bcd}$ & $144 \mathrm{a}$ & $144 \mathrm{a}$ & $144 \mathrm{a}$ & $144 \mathrm{a}$ \\
\hline El Toro & $349 \mathrm{abc}$ & 889 a & $324 \mathrm{a}$ & $601 \mathrm{a}$ & $216 \mathrm{a}$ & $241 \mathrm{a}$ & $144 \mathrm{a}$ & $156 \mathrm{a}$ \\
\hline Emerald & $324 \mathrm{bc}$ & $444 \mathrm{bc}$ & $264 \mathrm{ab}$ & $408 \mathrm{bcd}$ & $144 \mathrm{a}$ & $144 \mathrm{a}$ & $144 \mathrm{a}$ & $144 \mathrm{a}$ \\
\hline Empire & $421 \mathrm{a}$ & $684 \mathrm{ab}$ & $277 \mathrm{ab}$ & $504 \mathrm{abc}$ & $156 \mathrm{a}$ & $180 \mathrm{a}$ & $144 \mathrm{a}$ & $169 \mathrm{a}$ \\
\hline Jamur & $385 \mathrm{ab}$ & $745 \mathrm{a}$ & $300 \mathrm{a}$ & $432 \mathrm{abcd}$ & $144 \mathrm{a}$ & $144 \mathrm{a}$ & $144 \mathrm{a}$ & $144 \mathrm{a}$ \\
\hline Palisades & $421 \mathrm{a}$ & $684 \mathrm{ab}$ & $313 \mathrm{a}$ & $529 \mathrm{ab}$ & $144 \mathrm{a}$ & $144 \mathrm{a}$ & $144 \mathrm{a}$ & $144 \mathrm{a}$ \\
\hline$Y-2$ & $396 \mathrm{ab}$ & $444 \mathrm{bc}$ & $313 a$ & $349 \mathrm{~cd}$ & $144 \mathrm{a}$ & $144 \mathrm{a}$ & $144 \mathrm{a}$ & $144 \mathrm{a}$ \\
\hline Zeon & $264 \mathrm{c}$ & $349 \mathrm{c}$ & 192 c & $336 \mathrm{~cd}$ & $216 \mathrm{a}$ & $228 \mathrm{a}$ & $144 \mathrm{a}$ & $144 \mathrm{a}$ \\
\hline \multirow[t]{2}{*}{ Zorro } & $313 \mathrm{bc}$ & $396 \mathrm{c}$ & $216 \mathrm{bc}$ & $300 \mathrm{~d}$ & $144 \mathrm{a}$ & $144 \mathrm{a}$ & $144 \mathrm{a}$ & $144 \mathrm{a}$ \\
\hline & \multicolumn{2}{|c|}{0 DSD plugs } & \multicolumn{2}{|c|}{20 DSD plugs } & \multicolumn{2}{|c|}{40 DSD plugs } & \multicolumn{2}{|c|}{60 DSD plugs } \\
\hline Cultivar & 25 DAP & 56 DAP & 25 DAP & 53 DAP & 31 DAP & 61 DAP & 25 DAP & $57 \mathrm{DAP}$ \\
\hline Cavalier & $421 \mathrm{a}$ & $588 \mathrm{bc}$ & 372 bcd & 493 bc & $336 \mathrm{abc}$ & $493 \mathrm{bc}$ & $288 \mathrm{ab}$ & $421 \mathrm{bc}$ \\
\hline El Toro & $396 \mathrm{a}$ & 972 a & $444 \mathrm{~b}$ & $876 \mathrm{ab}$ & $408 \mathrm{abc}$ & $876 \mathrm{a}$ & $264 \mathrm{ab}$ & $372 \mathrm{c}$ \\
\hline Emerald & $372 \mathrm{a}$ & $493 \mathrm{c}$ & $360 \mathrm{~cd}$ & $552 \mathrm{bc}$ & $324 \mathrm{abc}$ & $457 \mathrm{c}$ & $241 \mathrm{~b}$ & 504 bc \\
\hline Empire & $457 \mathrm{a}$ & $768 \mathrm{abc}$ & $408 \mathrm{bc}$ & $601 \mathrm{bc}$ & $457 \mathrm{ab}$ & $828 \mathrm{a}$ & $336 \mathrm{ab}$ & $576 \mathrm{ab}$ \\
\hline Jamur & $444 \mathrm{a}$ & $864 \mathrm{ab}$ & $372 \mathrm{bcd}$ & $745 \mathrm{abc}$ & $396 \mathrm{abc}$ & $648 \mathrm{abc}$ & $300 \mathrm{ab}$ & 504 bc \\
\hline Palisades & $421 \mathrm{a}$ & $936 \mathrm{a}$ & $540 \mathrm{a}$ & 997 a & 493 a & $768 \mathrm{ab}$ & $385 \mathrm{a}$ & $684 \mathrm{a}$ \\
\hline $\mathrm{Y}-2$ & $396 \mathrm{a}$ & $696 \mathrm{abc}$ & $421 \mathrm{bc}$ & $624 \mathrm{abc}$ & $277 \mathrm{bc}$ & $349 \mathrm{c}$ & $336 \mathrm{ab}$ & $457 \mathrm{bc}$ \\
\hline Zeon & $372 \mathrm{a}$ & $504 \mathrm{c}$ & $313 \mathrm{~d}$ & $421 \mathrm{c}$ & $241 \mathrm{c}$ & $421 \mathrm{c}$ & $324 \mathrm{ab}$ & $480 \mathrm{bc}$ \\
\hline Zorro & $372 \mathrm{a}$ & $624 \mathrm{bc}$ & $349 \mathrm{~cd}$ & $457 \mathrm{c}$ & $313 \mathrm{abc}$ & $516 \mathrm{bc}$ & $300 \mathrm{ab}$ & $432 \mathrm{bc}$ \\
\hline
\end{tabular}

${ }^{\mathrm{z}}$ Area was calculated as the total area of all quadrat cells containing live plant material originating from the original plug.

${ }^{y}$ Values in a given column and year followed by the same letter do not differ at $P \leq 0.05$. 
to survive a $60-\mathrm{d}$ period without water. However, grasses grown on native soil with unrestricted rooting depth survived the 60 -d period without water. All grasses demonstrated progressively reduced lateral spread with increasing duration of time without water. These data emphasize the resiliency of warmseason turfgrasses after drought in the landscape. However, when evaluating potential impacts of water restrictions on turf, the turf species, root zone depth, soil type, duration of time without water, and environmental conditions must all be considered.

\section{Literature Cited}

Assmann, S.M. and K.L. Shimazaki. 1999. The multisensory guard cell, stomatal responses to blue light and abscisic acid. Plant Physiol. 119:809-815.

Beard, J. 1973. Turfgrass: Science and culture. Prentice-Hall, Englewood Cliffs, NJ.

Boyer, J.S. 1971. Recovery of photosynthesis in sunflower after a period of low leaf water potential. Plant Physiol. 47:816-820.

Cathey, S.E., J.K. Kruse, T.R. Sinclair, and M.D. Dukes. 2011. Tolerance of three warm-season turfgrasses to increasing and prolonged soil water deficit. HortScience 46:1550-1555.

Chalmers, D.R., K. Steinke, R.H. White, J.C. Thomas, and G. Fipps. 2008. Evaluation of sixty-day drought survival in San Antonio of established turfgrass species and cultivars. Final Report to the San Antonio Water System and the Turfgrass Producers of Texas.

DaCosta, M. and B. Huang. 2006. Changes in carbon partitioning and accumulation patterns during drought and recovery for colonial bentgrass, creeping bentgrass, and velvet bentgrass. J. Amer. Soc. Hort. Sci. 131:484-490.

DaCosta, M. and B. Huang. 2007. Drought survival and recuperative ability of bentgrass species associated with changes in abscisic acid and cytokinin production. J. Amer. Soc. Hort. Sci. 132:60-66.

Griffin, P.C. and A.A. Hoffmann. 2012. Mortality of Austalian alpine grasses (Poa spp.) after drought: Species differences and ecological patterns. J. Plant Ecol. 5:121-133.

Heckathorn, S.A., E.H. DeLucia, and R.E. Zielinski. 1997. The contribution of drought-related decreases in foliar nitrogen concentration to decreases in photosynthetic capacity during and after drought in prairie grasses. Physiol. Plant. 101:173-182.

Huang, B., R.R. Duncan, and R.N. Carrow. 1997a. Drought-resistance mechanisms of seven warm-season turfgrasses under surface soil drying: I. Shoot response. Crop Sci. 37:18581863.

Huang, B., R.R. Duncan, and R.N. Carrow. 1997b. Drought-resistance mechanisms of seven warm-season turfgrasses under surface soil drying: II. Root aspects. Crop Sci. 37:18631869.

Huang, B., J. Fry, and B. Wang. 1998. Water relations and canopy characteristics of tall fescue cultivars during and after drought stress. HortScience 33:837-840.

Marcum, K.B., M.C. Engelke, S.J. Morton, and R.H. White. 1995. Rooting characteristics and associated drought resistance of zoysiagrasses. Agron. J. 87:534-538.

Neumann, R.B. and Z.G. Cardon. 2012. The magnitude of hydraulic redistribution by plant roots: A review and synthesis of empirical and modeling studies. New Phytol. 194:337-352.
Qian, Y.L. and J.D. Fry. 1996. Irrigation frequency affects zoysiagrass rooting and plant water status. HortScience 31:234-237.

Qian, Y.L. and J.D. Fry. 1997. Water relations and drought tolerance of four turfgrasses. J. Amer. Soc. Hort. Sci. 122:129-133.

Qian, Y.L., J.D. Fry, and W.S. Upham. 1997. Rooting and drought avoidance of warm-season turfgrasses and tall fescue in Kansas. Crop Sci. 37:905-910.

Sheffer, K.M., J.H. Dunn, and D.D. Minner. 1987. Summer drought response and rooting depth of three cool-season turfgrasses. HortScience 22:296-297.

Soil Conservation Service, U.S. Department of Agriculture, Texas Agricultural Experiment Station. 1976. Soil survey laboratory data and descriptions for some soils of Texas. Soil Survey Investigations Report No. 30. U.S Government Printing Office. p. 178-179.

Steinke, K., D. Chalmers, J. Thomas, and R. White. 2011. Bermudagrass and buffalograss drought response and recovery at two soil depths. Crop Sci. 51:1215-1223.

Steinke, K., D. Chalmers, J. Thomas, R. White, and G. Fipps. 2010. Drought response and recovery characteristics of st. augustinegrass cultivars. Crop Sci. 50:2076-2083.

Trappe, J., A. Patton, D. Karcher, and M. Richardson. 2010. Divot recovery among bermudagrass and zoysiagrass cultivars-Year 2. Arkansas Turfgrass Report 2009. Ark. Ag. Exp. Stn. Res. Ser. 579:119-122.

Wang, Z. and B. Huang. 2004. Physiological recovery of kentucky bluegrass from simultaneous drought and heat stress. Crop Sci. 44:1729-1736.

White, R.H., A.H. Bruneau, and T.J. Cowett. 1993. Drought resistance of diverse tall fescue cultivars. Intl. Turf. Soc. Res. J. 7:607-613. 